\title{
ВЕКТОРИ РОЗВИТКУ МЕДИЧНОГО СТРАХУВАННЯ В УКРАÏHI
}

\section{VECTORS OF HEALTH INSURANCE DEVELOPMENT IN UKRAINE}

\author{
Водолазська Оксана Анатоліївна \\ кандидат економічних наук, \\ Дніпровський національний університет імені Олеся Гончара \\ ORCID: https://orcid.org/0000-0002-7858-7118 \\ Сіроштан Тетяна Миколаївна \\ студентка, \\ Дніпровський національний університет імені Олеся Гончара \\ ORCID: https://orcid.org/0000-0002-2697-8862 \\ Vodolazska Oksana, Siroshtan Tatiana \\ Oles Honchar Dnipro National University
}

\begin{abstract}
Стаття присвячена актуальним питанням розвитку медичного страхування в Україні. Розглянуто економічну сутність медичного страхування, підкреслено актуальність її дослідження та різноплановість. Визначено структуру медичного страхування з урахуванням фрорм та видів. Доведено, що страхування здоров'я - вагома частина соціальної інфрраструктури держави, що виступає насамперед допоміжною складовою медичної ссрери держави. Проаналізовано сучасний стан страхової медицини на страховому ринку України. Досліджено проблеми страхового захисту здоров'я, які перешкоджають його розвитку. Окреслено перспективи впровадження медичного страхування на загальнодержавному рівні та поетапність заходів, які треба виконати для його ефективного фрункціонування. Зазначено, що медичне страхування в даний час набирає популярності серед споживачів.

Ключові слова: страховий ринок, система охорони здоров'я, медичне страхування, добровільне медичне страхування, обов'язкове медичне страхування.
\end{abstract}

Статья посвящена актуальным вопросам развития медицинского страхования в Украине. Рассмотрена экономическая сущность медицинского страхования, подчеркнуто актуальность ее исследования и разноплановость. Определена структура медицинского страхования с учетом форм и видов. Доказано, что страхование здоровья - важная часть социальной инораструктуры государства, выступает прежде всего вспомогательной составляющей медицинской сореры государства. Проанализировано современное состояние страховой медицины на страховом рынке Украины. Исследованы проблемы страховой защиты здоровья, которые препятствуют её развитию. Определены перспективы внедрения медицинского страхования на общегосударственном уровне и поэтапность мер, которые необходимо выполнить для его эфффективного функционирования. Отмечено, что медицинское страхование в настоящее время набирает популярность среди потребителей.

Ключевые слова: страховой рынок, система здравоохранения, медицинское страхование, добровольное медицинское страхование, обязательное медицинское страхование.

The article is devoted to topical issues of health insurance development in Ukraine. The economic essence of health insurance is considered, which consists in belonging to the personal insurance system and is expressed in the form of insurance protection of the interests of individuals and legal entities, to cover their medical expenses at the expense of the created fund. The urgency of the study of health insurance for Ukraine is emphasized, as the state is currently carrying out medical reform, which aims to make the existing health care system more effective, further introducing health insurance at the national level. The structure of health insurance is determined taking into account the obligatory and voluntary forms, its types, namely continuous health insurance, sickness insurance and medical expenses insurance. It is proved that health insurance is an important part of the social infrastructure of the state, which is primarily an auxiliary component of the medical sphere of the state. Health insurance is able to fully meet the needs of the population in medical care. The current position of insurance medicine in the insurance market of Ukraine is analyzed. The place of health insurance for the insurance market on gross insurance premiums and payments is defined, the structure of the concluded agreements with clients is analyzed. The problems of health 
insurance that prevent its development have been studied. The main obstacles so far are underfunding of medicine, poorly functioning hospital infrastructure and too expensive health insurance policies for citizens. The prospects of introduction of health insurance at the national level and step-by-step measures to be taken for its effective functioning are told. Health insurance is currently gaining popularity among consumers, but most policyholders are still legal entities. New insurance products have been identified that are in great demand among the population, primarily insurance against COVID-19 infection. COVID-19 insurance offers inpatient and outpatient care, all medical expenses and some medical procedures. Usually with such insurance the insured event is a positive test for coronavirus, after which assistance is provided.

Keywords: insurance market, health care system, health insurance, voluntary health insurance, compulsory health insurance.

Постановка проблеми. В системі фрункціонування ринкового механізму сучасної держави одним 3 необхідних елементів $€$ медична галузь, бо саме лікарське обслуговування підтримує життя й нормальне самопочуття людського організму. В свою чергу, стан здоров'я людини $€$ показником добробуту країни та достатності фрінансування її медичної інфраструктури. Тому надання рівного доступу громадянам до медичного страхування є головною метою виконання державою її соціальних фрункцій. Сьогодні Україна тільки робить перші кроки до нової моделі системи охорони здоров'я, запровадивши медичну ресрорму.

Аналіз останніх джерел і публікацій. Дослідженню економічної сутності медичного страхування та його особливостей присвячували свої роботи багато українських науковців. Серед них найбільш виділилися такі дослідники: В.Д. Базилевич, О.О. Вороніна, Т.Ф. Григораш, В.О. Євсєєнко, Ю.П. Кіріченко, Н.Г. Нагайчук та інші. Варто зазначити, що в системі страхової медицини досі багато невирішених проблем, що пояснюється також відсутністю досконалого законодавства $з$ медичного страхування. Але не дивлячись на протиріччя тема $є$ актуальною і потребує подальшого дослідження.

Виділення невирішених раніше частин загальної проблеми. Одним 3 дискусійних питань $є$ механізм запровадження й особливості фрункціонування обов'язкового загальнодержавного страхування здоров'я. Взагалі метою обов'язкової фрорми медичного захисту $€$ накопичення страхових платежів у спеціальному фронді та фрінансування за рахунок нього лікувального обслуговування населення в законодавчо визначених обсягах. За сучасних умов фрункціонування ця форма медичного страхування в країні не $\epsilon$ дієвою у повному обсязі, оскільки медична ресорма незавершена, а законодавча невизначеність i труднощі у грошовому забезпеченні роботи лікувальних закла- дів не дають повного задоволення потреб населення від страхування. Добровільне страхування здоров'я теж варте уваги, бо його непоширеність та необізнаність щодо переваг й недоліків цього виду особистого страхування відштовхує потенційних страхувальників, навіть тих хто може собі дозволити поліс. Тож у даній статті розглянемо й проаналізуємо теперішний стан медичного страхування та запропонуємо можливі вектори його розвитку.

Формулювання цілей статті. Метою статті $\epsilon$ дослідження поняття медичного страхування, аналіз складової добровільного медичного страхування в системі сучасного страхового ринку і визначення перспективних векторів його розвитку.

Виклад основного матеріалу дослідження. Медичне страхування як доволі специфрічна сорера людського життя поки що не має точного трактування, яке б охоплювало усі особливості даної економічної категорії. У жодному законодавчому акті визначення страхової медицини не прописане чітко, що тільки розпалює суперечки фрахівців. В останніх законопроектах 3 приводу страхування здоров'я, а саме в проекті Закону України «Про загальнообов'язкове державне соціальне медичне страхування» значиться пояснення сутності загальнообов'язкового соціального медичного страхування, що виступає видом обов'язкового страхування, націленого, в першу чергу, на забезпечення конституційного права громадян на охорону здоров'я та на гарантування надання медичної допомоги й страхування безкоштовно. А от в іншому законопроекті «Про фрінансове забезпечення охорони здоров'я та загальнообов'язкове медичне страхування в Україні» зовсім відсутнє визначення страхової медицини, лише згадується медична допомога й послуги [10]. Доречно зауважити, що наведені вище проекти законів так і не були прийняті через надмірні грошові витрати при запровадженні страхування 
здоров'я громадян та нераціональність їх використання.

Провідні науковці - експерти галузі страхування трохи по-іншому розкривають значення медичного страхування. Так, В.Д. Базилевич зазначає, що страхування медицини $є$ однією з фрорм особового страхування, головною метою якої $\epsilon$ гарантоване забезпечення необхідним медичним обслуговуванням всього населення, лише за умови настання страхової події, коштом накопичень у страхових фондах [1, с. 163].

В.О. Євсєєнко більш стисло трактує поняття медичного страхування, тобто представляє дану форму особового страхування у вигляді механізму відшкодування витрат громадян, що спричинені хворобою або $€$ наслідком нещасного випадку [4, с. 32].

Т.Ф. Григораш та Ю.П. Кіріченко, як і В.Д. Базилевич, підкреслюють приналежність страхування здоров'я до системи особового страхування, а більш ширше, до галузі соціального страхування, і говорять, що медичне страхування $є$ одним із необхідних її елементів, яке слугує засобом реалізації принципів страхування [3, с. 140].

О.О. Вороніна наполягає на більш ширшому визначенні медичного страхування, яке б містило всі його особливості. На її думку, це страховий захист інтересів як юридичних, так і фрізичних осіб, при втраті ними здоров'я, незважаючи на причину, що пов'язане з покриттям грошових витрат громадян, спричинених наданням й оплатою медичної допомоги, інших процедур, покликаних підтримувати оптимальне самопочуття особи [2, с. 734].

Н.Г. Нагайчук у своєму трактуванні страхового захисту медичних витрат більшу увагу приділяє економічним складовим, аніж соціальним, та стверджує, що медичне страхування $€$ сукупністю певних економічних взаємовідносин страхувальника, страховика та інших суб'єктів, за яких страховик зобов'язаний сорормувати страхові резерви, за допомогою яких фрінансуються заходи 3 попередження страхової події чи зменшення негативних наслідків від неї, а страхувальник, в свою чергу, забезпечує собі чи іншій застрахованій особі право на одержання медичної послуги за прояву страхових ризиків, шляхом сплати належних страхових премій [8, с. 7].

Отже стає зрозуміло, що незважаючи на різноманітність думок щодо медичного страхування кожне визначення розкриває його особливості й показує, що суб'єктами таких відносин $є$ страховик, страхувальник (застрахована особа) й медичні організації, а головною метою - забезпечення лікарською допомогою громадян, які цього потребують.

Сьогодні страхова медицина в Україні, через відсутність обов'язкової її складової, представлена лише у добровільній срормі та частково доповнює фрінансування медичних послуг для окремих громадян.

В Україні валові страхові премії сегменту добровільного медичного страхування за 2016-2020 роки зросли аж на 2945 млн. грн. і склали у 2020 році 5300,50 млн. грн., а страхові виплати збільшилась вже на 1 399,20 млн. грн., відповідно в 2020 році сума валових страхових виплат дорівнювала 2 740,60 млн. грн. Поступово відбулося нарощення частки медичного страхування в системі страхового ринку з $6,70 \%$ у 2016 році до 11,73\% за 2020 рік. Така тенденція відображає більшу популярність даного виду особистого страхування, порівняно $з$ попередніми роками й активну конкуренцію серед страхових компаній. В свою чергу, рівень страхових виплат за 2016-2020 роки в середньому набув значення $57,09 \%$ та за 2019-2020 роки він мав певне скорочення 3 $58,71 \%$ у 2019 році до 51,70\% у 2020 році, але це не дуже вплинуло на загальну картину та підтверджує попередні висновки.

Законом України «Про страхування» регламентовано, що добровільне медичне страхування може проводитись у вигляді медичного страхування (безперервного страхування здоров'я), страхування медичних витрат та в формі страхування здоров'я на випадок хвороби [11]. Розглядаючи динаміку страхових премій за цими видами медичного страхування у 2016-2020 роках слід відзначити, що за 2016-2019 роки частка премій зі страхування медичних витрат поступово збільшувалася за рахунок скорочення частки премій за безперервним страхуванням здоров'я. Виключенням стала статистика за 2020 рік, де частка валових страхових премій за безперервним страхуванням здоров'я різко збільшилась, аж на 12,14 в.п., за рахунок чого питома вага премій за медичними витратами зменшилась на такий же відсоток. Пояснити такі зміни може пандемія COVID-19 у 2020 році, яка спровокувала зростання популярності медичного страхування.

Дослідження структури укладених договорів страхування у 2020 році доводить, що за цей рік більше всього укладали угод за 
страхуванням здоров'я на випадок хвороби, а найменше купували звичайну медичну страховку. Отже, у загальній кількість угод найбільшу частку складають страхові договори на випадок хвороби 40,31\%, за страхуванням медичних витрат число договорів трохи менше і дорівнює $36,87 \%$, а за безперервним - 22,82\%. Але досі більшою залишається частка страхувальників - юридичних осіб, що зацікавлені у здоров'ї своїх працівників [5].

Проаналізувавши теперішнє становище ринку добровільного страхування здоров'я можна констатувати його підвищену активність за останні роки. Страховики все жорсткіше конкурують між собою, розробляючи нові страхові програми для залучення фрізичних й юридичних осіб. За 2020 рік з'явився новий страховий продукт зі страхування від COVID-19 і саме це пояснює підвищену популярність такого страхування, як захист здоров'я на випадок хвороби. Зазвичай такі програми пропонують медичну допомогу при позитивному тесті на COVID-19 та як наслідок покриття витрат 3 амбулаторного лікування та перебування в стаціонарі.

Але страхова медицина не може працювати в повну силу за рахунок тільки ринку добровільного медичного страхування, запровадження обов'язкової фооми захисту здоров'я вкрай необхідне. Серед головних проблем, що перешкоджають старту функціонування обов'язкового медичного страхування можемо виділити:

- недостатність фрінансування системи охорони здоров'я, а саме прагнення уряду економити витрати на медицину;

- погана підготовка медичного персоналу у закладах освіти та низькі заробітні плати у медичних закладах;

- суперечки науковців, законодавців і діячів органів виконавчої влади з приводу стратегії запровадження обов'язкового страхування здоров'я;

- необізнаність громадян щодо медичного страхування та недовіра до страхових організацій [6, с. 723];

- висока вартість полісів страхування разом із зазвичай низькими доходами громадян, на фроні зростання цін товарів першої необхідності та комунальних платежів;

- нечіткість та неефективність роботи існуючої інфрраструктури медичних закладів [7, c. 64].

Кілька років тому урядом було розпочато медичну рефрорму, яка $є$ одним із елементів перетворення медичної ссрери України та етапи якої зазначені в «Національній стратегії реформування системи охорони здоров'я в Україні на період 2015-2020 років» [9]. Експерти вважають, що позитивним зрушенням $€$ поступовий перехід від радянської системи організації охорони здоров'я до нової, більш сучасної системи, яка б поєднувала обов'язкове й добровільне страхування здоров'я. Зараз вже визначена базова модель фрінансування галузі лікування громадян, нею стала іспанська модель, звичайно ж адаптована до українських реалій.

Відповідно до Національної стратегії рефрормування, слід визначити подальші перспективи перетворення сорери охорони здоров'я, а саме: скасування нав'язування лікарні за пропискою, нові правила звітування медичних закладів і прийняття закону про загальнообов'язкове медичне страхування, за яким держава надаватиме базовий пакет медичних послуг, а страхові компанії додатковий [9].

Але виконання даних заходів призупинила пандемія. Уряд України змушений витрачати багато коштів на підтримку лікарень, які приймають у себе пацієнтів з COVID-19 та грошові винагороди й надбавки медичному персоналу. Тому навіть під кінець 2021 року запровадження обов'язкової форми страхової медицини не планується і вже існують прогнози щодо зрушень у введенні в дію закону лише на 2023 рік.

Висновки. Безперечно, страховий захист здоров'я населення $\epsilon$ вагомою частиною медичної ссрери, а обов'язкова та добровільна форма разом покликані задовольнити усі потреби застрахованих. Відмінність в тому, що обов'язкове медичне страхування надає обмежений перелік послуг, а добровільне - більш розширений. Станом на 2021 рік обов'язковий страховий захист не запроваджено на загальнодержавному рівні.

Аналіз сегменту добровільного медичного страхування підтвердив його підвищену активність та щорічне зростання кількості укладених угод. Все це вказує на підвищення попиту як серед населення, так і серед роботодавців, які останнім часом зацікавилися у купівля медичної страховки для персоналу.

Маємо надію, що все це дасть поштовх до прийняття закону про медичне страхування, більше громадян задовольнятимуть свої потреби у лікарських послугах, а діяльність страхових організацій у сорері медичного страхування стане ще активнішою. 


\section{СПИСОК ВИКОРИСТАНИХ ДЖЕРЕЛ:}

1. Базилевич В.Д., Базилевич К.С., Пікус Р.В. Страхування : підруч. Київ : Знання, 2008. 1019 с.

2. Вороніна О.О. Наукові підходи до визначення сутності медичного страхування. Вісник Миколаївського національного університету імені В.О. Сухомлинського. 2015. № 8. С. 733-737.

3. Григораш Т.Ф., Кіріченко Ю.П. Перспективи розвитку медичного страхування на ринку страхових послуг в Україні. Економічний простір. 2011. № 56/2. С. 138-148.

4. Євсєєнко В.О. Форми медичного страхування та його організаційні основи. Вісник ДДФА : Економічні науки. 2009. № 2. С. 31-33.

5. Консолідований звіт діяльності страхових компаній за 2016-2020pp. URL: https://bank.gov.ua/ua/statistic/ supervision-statist/data-supervision\#6 (дата звернення: 21.04.2021).

6. Костенко Т.А., Скотолюк В.В., Заволока Л.О. Стан та перспективи розвитку медичного страхування в Україні з урахуванням іноземного досвіду. Молодий вчений. 2018. № 5. С. 721-725.

7. Коцюбра О.Ю., Грешнікова М.О. Сучасний стан та перспективи розвитку добровільного медичного страхування в Україні. Вісник Кіровоградського національного технічного університету : Наукові записки. 2017. № 13. С. $62-64$.

8. Нагайчук Н.Г. Формування системи добровільного медичного страхування в умовах ринкової економіки : автореф. дис. на здобуття наук. ступеня. канд. екон. наук : 08.04.01 Київ, 2006. 22 с.

9. Національна стратегія реформування системи охорони здоров'я в Україні на період 2015-2020 рр.

URL: https://uoz.cn.ua/strategiya.pdf (дата звернення: 22.04.2021).

10. Про загальнообов'язкове державне соціальне медичне страхування в Україні : Проект Закону України від 2 серп. 2016 р. № 4981-2. URL: https://ips.ligazakon.net/document/view/JH3UD1BA (дата звернення: 20.04.2021).

11. Про страхування : Закон України від 7 бер. 1996 р. № 85/96-BP. URL: https://zakon.rada.gov.ua/laws/ show/85/96-вр (дата звернення: 20.04.2021).

\section{REFERENCES:}

1. Bazilevich, V.D., Bazilevich, K.S. \& Picus, R.V. (2008). Strakhuvannia [Insurance]. Kyiv: Znannia, 1019 p. (in Ukrainian)

2. Voronina, O.O. (2015). Naukovi pidkhody do vyznachennia sutnosti medychnoho strakhuvannia [Scientific approaches to defining the essence of health insurance]. Visnyk Mykolaivskoho natsionalnoho universytetu imeni V.O. Sukhomlynskoho, no. 8, pp. 733-737.

3. Grigorash, T.F. \& Kirichenko, Y.P. (2011). Perspektyvy rozvytku medychnoho strakhuvannia na rynku strakhovykh posluh $\vee$ Ukraini [Prospects for the development of health insurance in the insurance market in Ukraine]. Ekonomichnyi prostir, no. 56/2, pp. 138-148.

4. Evseenko, V.O. (2009). Formy medychnoho strakhuvannia ta yoho orhanizatsiini osnovy [Forms of health insurance and its organizational basis]. Visnyk DDFA: Ekonomichni nauky, no. 2, pp. 31-33.

5. Konsolidovanyi zvit diialnosti strakhovykh kompanii za 2016-2020 rr. [Consolidated report on the activities of insurance companies for 2016-2020]. Available at: https://bank.gov.ua/ua/statistic/supervision-statist/data-supervision\#6 (accessed 21 April 2021).

6. Kostenko, T.A., Skotolyuk, V.V. \& Zavoloka, L.O. (2018). Stan ta perspektyvy rozvytku medychnoho strakhuvannia $v$ Ukraini $z$ urakhuvanniam inozemnoho dosvidu [The situation and prospects for the development of health insurance in Ukraine, taking into account foreign experience]. Molodyi vchenyi, no. 5, pp. 721-725.

7. Kotsyubra, O.Y. \& Greshnikova, M.O. (2017). Suchasnyi stan ta perspektyvy rozvytku dobrovilnoho medychnoho strakhuvannia $v$ Ukraini [Current situation and prospects for the development of voluntary health insurance in Ukraine]. Visnyk Kirovohradskoho natsionalnoho tekhnichnoho universytetu: Naukovi zapysky, no. 13, pp. 62-64.

8. Nagaychuk, N.G. (2006). Formuvannia systemy dobrovilnoho medychnoho strakhuvannia $v$ umovakh rynkovoi ekonomiky [Formation of a system of voluntary health insurance in a market economy]. Extended abstract of Candidate's thesis. Kyiv. (in Ukrainian)

9. Natsionalna stratehiia reformuvannia systemy okhorony zdorovia v Ukraini na period 2015-2020 rr. [National strategy for reforming the health care system in Ukraine for the period 2015-2020]. Available at: https://uoz.cn.ua/ strategiya.pdf (accessed 22 April 2021).

10. Pro zahalnooboviazkove derzhavne sotsialne medychne strakhuvannia v Ukraini: Proekt Zakonu Ukrainy vid 2 serp. 2016 r. № 4981-2 [On compulsory state social health insurance in Ukraine: Draft Law of Ukraine of August 2 2016 № 4981-2] (2016). Available at: https://ips.ligazakon.net/document/view/JH3UD1BA (accessed 20 April 2021).

11. Pro strakhuvannia: Zakon Ukrainy vid 7 ber. 1996 r. № 85/96-VR [On insurance: Law of Ukraine of March 71996 № 85/96-VR] (1996). Available at: https://zakon.rada.gov.ua/laws/show/85/96-вp (accessed 20 April 2021). 